\title{
IMPROVED APEX MODEL SIMULATION OF BUFFER WATER QUALITY BENEFITS AT FIELD SCALE
}

\author{
G. M. M. M. A. Senaviratne, C. Baffaut, J. A. Lory, R. P. Udawatta, \\ N. O. Nelson, J. R. Williams, S. H. Anderson
}

\begin{abstract}
Watershed models offer cost-effective means to quantify the environmental benefits of conservation practices. This study evaluated the ability of the Agricultural Policy/Environmental eXtender (APEX) model to simulate the effectiveness of upland buffers for reducing event runoff, sediment, and total phosphorus (TP) loadings. The study used 16 years of monitoring data (1993-2008) from three field-scale row crop watersheds. Two watersheds had buffers installed in the fall of 1997, one with upland agroforestry buffers (grass plus trees) and the second with upland grass buffers; the third watershed was maintained as a control. Objectives were to (1) determine the effect of upland buffers on APEX parameters, (2) evaluate the ability of APEX to estimate upland buffer effectiveness, and (3) evaluate the impact of alternative buffer placement options on water quality outcomes. After modification of the APEX code to improve simulation of infiltration in the buffers, we successfully calibrated APEX for no-buffer and upland buffer conditions for event runoff and TP. However, calibrated parameters from the no-buffer model simulated buffer conditions poorly and resulted in an overestimation of buffer effectiveness. Buffer effectiveness estimated with upland buffer parameters was similar to that obtained from measured data. Scenario analysis indicated that a combination of backslope and footslope agroforestry buffers was more effective than contour placement for reducing average annual edge-of-field runoff and total P losses. These results highlight the complexity of using APEX to assess upland buffers as well as potential problems when using APEX to quantify the benefits of conservation practices not included in the calibration dataset.
\end{abstract}

Keywords. Agroforestry buffers, Buffer placement, Modeling, Phosphorus, Practice effectiveness, Watershed discretization.

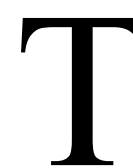
he contribution of agricultural pollutants to deterioration of water quality is a global issue. Mitigation efforts are challenging because of the distributive nature of the pollution. Vegetative strips placed within (upland buffers) or at the edge of a field are effective conservation measures to reduce sediment and nutrient loadings from agricultural fields (Lowrance et al., 1984; Dillaha et al., 1989; Schmitt et al., 1999; Lee et al.,

\footnotetext{
(c) (1) $\odot$ The authors have paid for open access for this article. This (c) ${ }_{\mathrm{BY}} \mathrm{NC}_{\mathrm{ND}}$ work is licensed under a Creative Commons AttributionNonCommercial-NoDerivatives 4.0 International License https://creative commons.org/licenses/by-nc-nd/4.0/

Submitted for review in October 2017 as manuscript number NRES 12655; approved for publication by the Natural Resources \& Environmental Systems Community of ASABE in December 2017.

Mention of company or trade names is for description only and does not imply endorsement by the USDA. The USDA is an equal opportunity provider and employer.

The authors are G. M. M. M. Anomaa Senaviratne, Research Scientist, School of Natural Resources, University of Missouri, Columbia, Missouri; Claire Baffaut, Research Hydrologist, USDA-ARS Cropping Systems and Water Quality Research Unit, Columbia, Missouri; John A. Lory, Associate Professor, Plant Science Division, University of Missouri, Columbia, Missouri; Ranjith P. Udawatta, Professor, Center for Agroforestry, University of Missouri, Columbia, Missouri; Nathan O. Nelson, Professor, Department of Agronomy, Kansas State University, Manhattan, Kansas; Jimmy R. Williams, Senior Research Scientist, Blackland Research and Extension Center, Temple, Texas; Stephen H. Anderson, Professor, School of Natural Resources, University of Missouri, Columbia, Missouri. Corresponding author: Claire Baffaut, USDA-ARS, 241 Ag. Eng. Bldg., University of Missouri, Columbia, MO 65211; phone: 573-882-1114, ext. 315; e-mail: Claire.Baffaut@ars.usda.gov.
}

2000). Given the limits of measured data, process-based models may be an alternative for estimating long-term sediment and phosphorus (P) losses (Sharpley et al., 2012). Models could be used to extend existing measured data to provide quantitative estimates of runoff, sediment, and P loss under alternative weather scenarios and/or varying management at one site, or under varying soils, topography, and climate across a region. However, models have yet to be fully evaluated for their capacity to simulate sediment and P loss from the complex agroecosystems created by upland buffers.

Permanent vegetation in buffers removes sediment, nutrients, and pesticides from surface runoff water through filtration, deposition, adsorption, and infiltration (Dillaha et al., 1989, Lerch et al., 2017) and by increased degradation of some compounds (Lin et al., 2008). Studies have documented increased infiltration rates in buffers (Schmitt et al., 1999) due to improved soil porosity and hydraulic conductivity (Udawatta and Anderson, 2008; Kumar et al., 2011; Larson and Safferman, 2012). Seobi et al. (2005) and Kumar et al. (2012) determined that soil hydraulic conductivity values were four to 16 times higher in an agroforestry buffer than in the associated cropland or pasture. Reported trapping effectiveness values of upland and edge-of-field buffers vary widely among studies: from $41 \%$ to $100 \%$ for sediment and from $27 \%$ to $96 \%$ for total phosphorus (TP) (Dillaha et al., 1989; Daniels and Gilliam, 1996; Schmitt et al., 1999; Mayer et al., 1999; Lee et al., 2000; Blanco-Canqui et al., 2004; Vianello et al., 2005; Bhattarai et al., 2009; Caron et al., 2010; Al-wadaey et al., 2012). 
Most buffer effectiveness studies were conducted at the plot scale, with unsubmerged vegetation, and with drainage area to buffers ratios of less than 20:1 (Helmers et al., 2008). At field scale, effectiveness may be lower because of larger drainage area to buffer ratios and longer slope lengths, leading to increased concentrated flow (Helmers et al., 2008, 2012). In Iowa, a long-term replicated field experiment quantified the effectiveness of different combinations of edge-of-field and upland prairie buffers in 12 small watersheds (areas of 0.47 to 3.19 ha; Helmers et al., 2012; Zhou et al., 2014). Reported trapping effectiveness was $96 \%$ for sediment (Helmers et al., 2012) and $82 \%$ for TP over five years (Zhou et al., 2014). A long-term Missouri study with three watersheds (areas of 1.65 to $4.44 \mathrm{ha}$ ), using a paired watershed approach, compared contour upland grass or agroforestry buffers ( $4.5 \mathrm{~m}$ width) to a control watershed (Udawatta et al., 2011). Reported trapping effectiveness was lower than the Iowa study: $15 \%$ to $23 \%$ for runoff, $28 \%$ to $30 \%$ for sediment, and $22 \%$ to $26 \%$ for TP loads over five years. These two unique field-scale studies document the potential for significant variation in the performance of upland buffers, possibly due to variations in slope, vegetation density, flow rate, soils, buffer width, and placement characteristics (Gumiere et al., 2011). From a literature review, Gumiere et al. (2011) concluded that sediment removal was maximized when vegetated buffers were placed at the downstream edge of agricultural fields, close to the outlet. The use of models to evaluate the effects of spatial organization of buffers is essential, as field experimentation for such evaluations is very expensive and difficult to apply.

The Agricultural Policy/Environmental eXtender (APEX) model (Williams and Izaurralde, 2006) was specifically developed to simulate the water quality impacts of agricultural production in field-scale watersheds. APEX is a physically based model and works on a continuous daily time step. Spatial heterogeneity of a watershed is represented by dividing the watershed into subareas that are homogeneous in soil, land use, land management, and topography. Water, sediment, and nutrients are routed through subareas in transit to the edge-of-field. Because of its capabilities in simulating diverse conservation practices (Gassman et al., 2010; Tuppad et al., 2010; Mudgal et al., 2012), including buffers and filter strips (Williams et al., 2006), APEX was used for conservation assessments by the national Conservation Effects Assessment Project (CEAP) of the USDA Natural Resources Conservation Service (https://www.nrcs.usda.gov/ wps/portal/nrcs/main/national/technical/nra/ceap/; Santhi et al., 2014).

Buffers shorten slope length by intercepting flow from the upstream crop area and spreading it through the vegetation, providing opportunities for infiltration and sediment deposition (Dillaha et al., 1989; Blanco-Canqui et al., 2004). Simulating upland buffers in a field requires the definition of separate subareas (one for each buffer) to capture the differences in vegetation and soil properties compared to the crop area. The result is a field delineated at a higher spatial resolution and with a denser channel network than a field with no upland buffers. The denser channel network results in increased total length of channels in the watershed while shortening surface flow pathways (slope lengths). Studies that looked at the impact of spatial resolution, i.e., subdivision of the study area into smaller units, have been conducted for SWAT (Haverkamp et al., 2002, Muleta et al. 2007; Arabi et al., 2008; Her et al. 2015). All these studies concurred that runoff and discharge were not affected by the spatial resolution with SWAT, but sediment and nutrients were significantly affected by the increasing channel length, which also increased the impact of channel routing processes because all the channel processes are simulated proportional to their length. This topic has not been discussed with APEX; the impact of the buffer delineation method on model results needs to be investigated.

This study used long-term monitoring data from three field-scale watersheds in Knox County, Missouri, two of which had upland buffers (Udawatta et al., 2011), to evaluate the ability of APEX to simulate the benefits of upland buffers on edge-of-field sediment and P export. Specific objectives were to (1) determine the effect of upland buffers on APEX parameters, (2) evaluate the ability of APEX to estimate upland buffer effectiveness, and (3) evaluate the impact of alternative buffer placement on water quality outcomes.

\section{MATERIALS AND MeTHODS}

\section{Site DESCRIPTION AND MONITORING DATA}

Data for the study were obtained from three long-term monitored field-scale watersheds (fig. 1), i.e., West (3.16 ha), Center (4.44 ha), and East (1.54 ha), located in Knox County, Missouri, at the University of Missouri Greenley Memorial Research Center $\left(40^{\circ} 1^{\prime} \mathrm{N}, 92^{\circ} 11^{\prime} \mathrm{W}\right)$ (Udawatta et al., 2002, 2011). Slopes within the watersheds

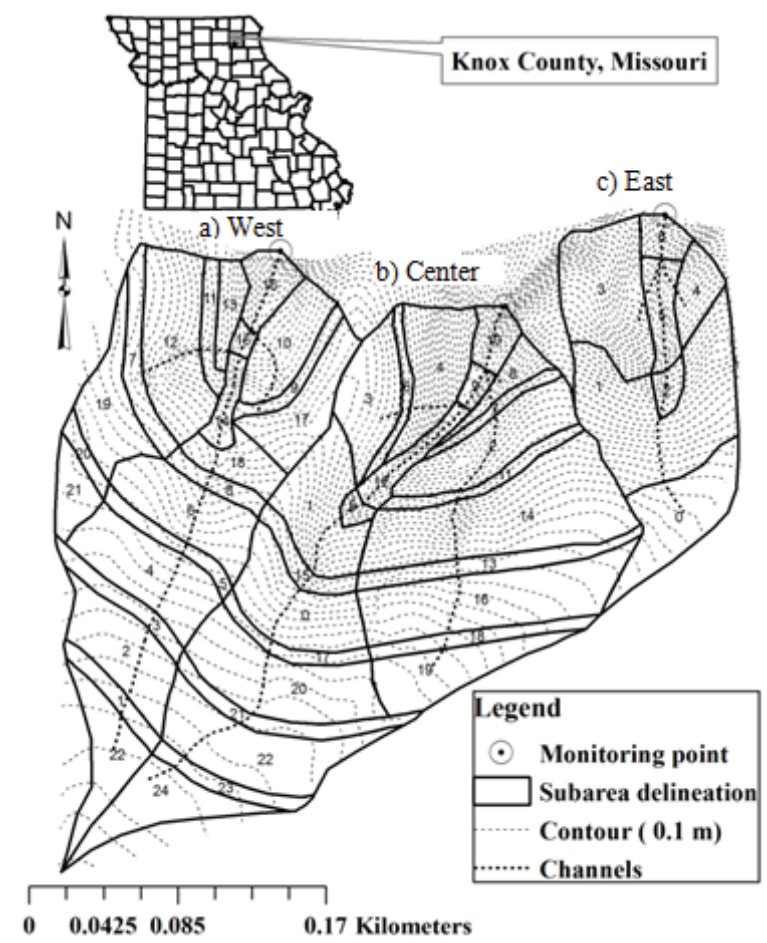

Figure 1. Map of contours, subareas, and channel network developed for APEX model simulations of the grass buffer (West, 3.16 ha), agroforestry buffer (Center, $4.44 \mathrm{ha}$ ), and control (East, 1.65 ha) watersheds at Greenley Memorial Research Center, Missouri. The strips parallel to the contour lines show the contour buffers. 
Table 1. Soil characteristics of the Center, West, and East watersheds located at Greenley Memorial Research Center, Missouri.

\begin{tabular}{|c|c|c|c|c|}
\hline & & & Natershed & \\
\hline & $\begin{array}{c}\text { Soil Series with } \\
\text { Surface Textural Class }\end{array}$ & $\begin{array}{c}\text { West } \\
(3.16 \mathrm{ha})\end{array}$ & $\begin{array}{c}\text { Center } \\
(4.44 \text { ha })\end{array}$ & $\begin{array}{c}\text { East } \\
(1.54 \mathrm{ha})\end{array}$ \\
\hline & Armstrong loam ${ }^{[\mathrm{a}]}$ & $6 \%$ & $20 \%$ & $41 \%$ \\
\hline & Kilwinning silt loam ${ }^{[\mathrm{b}]}$ & $32 \%$ & $31 \%$ & $40 \%$ \\
\hline & Putnam silt loam ${ }^{[\mathrm{c}]}$ & $62 \%$ & $49 \%$ & $19 \%$ \\
\hline $\begin{array}{l}\text { [b] } \\
\text { [c] }\end{array}$ & $\begin{array}{l}\text { Fine, smectitic, mesic } \\
\text { Fine, smectitic, mesic }\end{array}$ & $\begin{array}{l}\text { Halpud } \\
\text { iaqualf; } \\
\text { lbaqualf }\end{array}$ & $\begin{array}{l}\text { o to } 9 \% \text { s } \\
\text { o } 5 \% \text { slop } \\
\text { o } 1 \% \text { slop }\end{array}$ & \\
\hline
\end{tabular}

ranged from $0 \%$ to $6 \%$. All soils (table 1 ) had a characteristic poorly drained argillic horizon, known as a claypan, within 0.1 to $0.5 \mathrm{~m}$ depth (Miles and Hammer, 1989), resulting in soil hydrologic group D classification. The Novelty weather station (http://agebb.missouri.edu/) located $\sim 1.2 \mathrm{~km}$ south of the watersheds provided daily measured precipitation and minimum and maximum temperature data for model input.

The cropped areas of all three watersheds were managed as a no-till, contour planted, corn (Zea mays L.) - soybean [Glycine max (L.) Merr.] rotation from 1991-2008 except for 1992, when field cultivation was used for field preparation. All watersheds had a grass waterway ('Kentucky 31' tall fescue grass [Lolium arundinaceum (Schreb.) Darbyish.]). In the fall of 1997, multiple upland contour grass-legume buffers, $4.5 \mathrm{~m}$ wide, were installed in the West and Center watersheds (fig. 1). The grass-legume combination included redtop (Agrostis gigantea Roth), smooth bromegrass (Bromus inermis L.), and birdsfoot trefoil (Lotus corniculatus L.). Also in fall 1997, a tree line was planted at the center of each upland grass buffer in the Center watershed (upland agroforestry buffers). Pin oak (Quercus palustris Muench), bur oak (Q. macrocarpa Michx.), and swamp white oak (Q. bicolor Willd.) were alternately planted in the center of the buffer strips at a $3 \mathrm{~m}$ spacing, resulting in 333 trees planted. Dead trees (1\%) were replanted in 2000 for a final tree density of 76 trees ha $^{-1}$. Average tree height grew from $2.1 \mathrm{~m}$ in 2002 to $5.3 \mathrm{~m}$ in 2010 , and average diameter $10 \mathrm{~cm}$ above ground grew from $6.5 \mathrm{~cm}$ in 2002 to $11 \mathrm{~cm}$ in 2005 (Udawatta et al., 2005). The East watershed was kept as the control (Udawatta et al., 2011).

Field operations during the no-buffer (1993-1997) and upland buffer periods (1998-2008) were obtained from the farm manager of Greenley Experiment Station. Fertilizers application rates ranged from 150 to $160 \mathrm{~kg} \mathrm{ha}^{-1}$, from 21 to
$35 \mathrm{~kg} \mathrm{ha}^{-1}$, and from 83 to $100 \mathrm{~kg} \mathrm{ha}^{-1}$ of elemental N, P, and $\mathrm{K}$, respectively, and were surface applied at spring planting in corn years. In each watershed, the grass waterway led to a concrete approach section, an $\mathrm{H}$-flume, a bubbler flowmeasuring device, and a water sampling unit (ISCO Inc., Lincoln, Neb.). Flow-weighted runoff samples $(135 \mathrm{~mL}$ sample of runoff after each $25 \mathrm{~m}^{3}$ of flow) were collected for each storm event between February/March and late December, and a composite sample was analyzed for total suspended sediment and TP. A total of 47 runoff events were recorded in each watershed from 1993 to 1997 (no-buffer period), and 42 events were recorded from 1998 to 2008 (upland buffer period). The numbers of sediment and TP data available for each watershed varied and are provided in table 2. Other details not included in this summary of the research methods for the 16-year data collection period can be found in Udawatta et al. $(2002,2004,2011)$.

\section{MODIFICATION OF APEX FOR IMPROVED \\ BUFFER SIMULATION}

APEX version 0806 was used in this study. APEX simulates surface runoff from each subarea and concentrates it into a channel that routes the flow from that subarea to the watershed outlet. When the channel capacity within a subarea is exceeded by inflow and runoff generated in the subarea, flow and infiltration expand in the floodplain, i.e., the cropland or the grass area on either side of the channel. In these watersheds, channels were very small $(3$ to $20 \mathrm{~cm}$ width), and the floodplains were 30 times larger. APEX handles the water in subareas designated as buffers differently from other subareas. Incoming water in channels is redistributed by considering the entire subarea to be a floodplain in order to simulate the spreading of overland flow through buffers; a user-defined parameter allows a fraction of the incoming runoff to concentrate and bypass the buffer (Dillaha et al., 1989). The initial formulation of APEX0806 allowed only one floodplain hydraulic conductivity for the whole watershed, which constrained our ability to represent the range of infiltration rates in the floodplains around channels in cropped areas and in the buffers. We modified the APEX code to define subarea-specific floodplain values of saturated hydraulic conductivity $\left(K_{s a t}\right)$. Instead of a global floodplain $K_{\text {sat }}$ specified in the control file, subarea floodplain $K_{\text {sat }}$ values were calculated as a function of subarea soil $K_{\text {sat }}$. This

Table 2. Characteristics and water quality data availability for the watersheds located at Greenley Memorial Research Center, Missouri.

\begin{tabular}{|c|c|c|c|c|c|c|c|}
\hline \multirow{2}{*}{\multicolumn{2}{|c|}{ Characteristic }} & \multicolumn{6}{|c|}{ Monitoring Data Set } \\
\hline & & $\begin{array}{l}\text { Center, } \\
\text { No Buffer }\end{array}$ & $\begin{array}{c}\text { West, } \\
\text { No Buffer }\end{array}$ & $\begin{array}{c}\text { Control } \\
\text { (East), } \\
\text { No Buffer }\end{array}$ & $\begin{array}{c}\text { Center, } \\
\text { Upland Buffers }\end{array}$ & $\begin{array}{c}\text { West, } \\
\text { Upland Buffers }\end{array}$ & $\begin{array}{c}\text { Control } \\
\text { (East), } \\
\text { No Buffer }\end{array}$ \\
\hline \multicolumn{2}{|c|}{ Monitoring period } & 1993-1997 & 1993-1997 & 1993-1997 & $1998-2008$ & $1998-2008$ & $1998-2008$ \\
\hline \multicolumn{2}{|c|}{$\begin{array}{c}\text { Structural conservation } \\
\text { practices }\end{array}$} & $\begin{array}{c}\text { Grass } \\
\text { waterway }\end{array}$ & $\begin{array}{c}\text { Grass } \\
\text { waterway }\end{array}$ & $\begin{array}{c}\text { Grass } \\
\text { waterway }\end{array}$ & $\begin{array}{l}\text { Grass waterway, } \\
\text { five grass plus tree } \\
\text { contour buffer }\end{array}$ & $\begin{array}{c}\text { Grass waterway, } \\
\text { five grass contour } \\
\text { buffers }\end{array}$ & $\begin{array}{c}\text { Grass } \\
\text { waterway }\end{array}$ \\
\hline \multirow{3}{*}{$\begin{array}{l}\text { Runoff } \\
(\mathrm{mm})\end{array}$} & No. of events & 47 & 47 & 47 & 42 & 42 & 42 \\
\hline & Median & 13.7 & 18.9 & 15.7 & 16.5 & 20.5 & 21.3 \\
\hline & Range & 0.6 to 93.2 & 0.6 to 140.5 & 0.9 to 148.7 & 2.0 to 75.2 & 0.6 to 109.2 & 0.8 to 110 \\
\hline \multirow{3}{*}{$\begin{array}{l}\text { Sediment } \\
\left(\mathrm{kg} \mathrm{ha}^{-1}\right)\end{array}$} & No. of events & 43 & 41 & 43 & 30 & 28 & 29 \\
\hline & Median & 10.0 & 14.0 & 9.0 & 3.0 & 3.0 & 5.0 \\
\hline & Range & 0.3 to 1090.0 & 0.2 to 1090.0 & 0.4 to 1170.8 & 0.3 to 49.0 & 0.3 to 37.0 & 0.1 to 37.7 \\
\hline \multirow{3}{*}{$\begin{array}{c}\text { Total } \\
\text { phosphorus } \\
\left(\mathrm{kg} \mathrm{ha}^{-1}\right)\end{array}$} & No. of events & 43 & 41 & 43 & 20 & 20 & 20 \\
\hline & Median & 0.099 & 0.106 & 0.069 & 0.074 & 0.08 & 0.08 \\
\hline & Range & 0.0029 to 0.60 & 0.0023 to 0.83 & 0.0025 to 0.67 & 0.008 to 0.44 & 0.005 to 0.63 & 0.004 to 0.67 \\
\hline
\end{tabular}


allowed variation in the infiltration rates among floodplains in upland buffers, grass waterways, and cropland. Cropland $K_{\text {sat }}$ values ranged from 10 to $16 \mathrm{~mm} \mathrm{~h}^{-1}$ in the top soil depth of different soil series and were $0.007 \mathrm{~mm} \mathrm{~h}^{-1}$ in the claypan. Buffer $K_{\text {sat }}$ values of the top soil layer were increased to $25 \mathrm{~mm} \mathrm{~h}^{-1}$ for the Putnam and Kilwinning series and to $30 \mathrm{~mm} \mathrm{~h}^{-1}$ for the Armstrong series. Buffer $K_{\text {sat }}$ in the claypan was increased to $15 \mathrm{~mm} \mathrm{~h}^{-1}$ for the Putnam series in the agroforestry buffers and to $1.9 \mathrm{~mm} \mathrm{~h}^{-1}$ for the Kilwinning series in the grass buffers, based on measurements by Seobi et al. (2005). Floodplain $K_{\text {sat }}$ for the whole profile was set at a small fraction (0.00005) of the top soil value. APEX floodplain $K_{\text {sat }}$ values are always smaller than the corresponding soil values to avoid excessive infiltration in the floodplain (Steglich and Williams, 2013). In addition, they represent the conductivity of the whole profile and need to incorporate the effect of the claypan on overall infiltration.

\section{Model Parameterization (OBJective 1)}

In a typical study of buffer effectiveness, the model is calibrated for a field without buffers. The model is then run with buffers added, and the results are compared to the no-buffer situation. Alternatively, the model is calibrated with buffers, and those buffers are then removed from the model to estimate what sediment and phosphorus losses would have been if the buffers had not been present. For objective 1, we tested whether a model calibrated and validated without buffers meets the performance criteria when buffers are simulated, and vice versa. Finally, we identified differences and similarities among all the parameter sets that provide acceptable performance.

\section{No-Buffer (NB) Model Parameterization}

Discretization of these watersheds was carried out in the ArcGIS environment (ESRI, Redlands, Cal.). Contour maps available for the site were used to create $0.25 \mathrm{~m}$ digital elevation maps (DEM) from which flow pathways were defined using the fill, flow accumulation, flow direction, and watershed hydrology tools in ArcGIS. Soil maps from the USDANRCS Soil Survey Geographic Database (SSURGO) (http://websoilsurvey.sc.egov.usda.gov/), land use imagery maps from the USGS Multi-Resolution Land Characteristic Consortium (https:/www.mrlc.gov/), contour maps, and flow pathway maps were used to manually delineate watersheds into subareas homogenous in land use, topography, and soil using ArcGIS editing tools. Grass waterways were simulated as separate subareas planted with grass. Parameters used to define each land use type were selected based on guidelines in the APEX manual (Steglich and Williams, 2013) and are listed in table 3.

Soil texture was determined by horizon from 30 (Center and West watersheds) and 20 (East watershed) $1 \mathrm{~m}$ deep soil cores collected in 1994 and 2000 with GPS locations (Udawatta et al., 2004, 2015). Saturated conductivity and bulk density were measured at six cropland locations, six agroforestry buffer locations, and six grass buffer locations in the Center watershed on 0-10, 10-20, 20-30, and 30-40 cm deep cores collected in 2003 (Seobi et al., 2005). Soil samples (20 cores per sample, $0-5 \mathrm{~cm}$ and $5-15 \mathrm{~cm}$ depths) were collected in 2014 in each major combination of soil type and land use in each watershed. These samples were analyzed for $\mathrm{pH}$, organic matter content, Bray-1 $\mathrm{P}$, and cation exchange capacity using standard methods (Nathan et al., 2012). The equation suggested by Mallarino and Atia (2005) was used to estimate anion exchangeable phosphorus (AEP) content based on Bray-1 P. The soil phosphorous sorption ratio (PSP) was estimated using the equation suggested by Nelson and Parsons (2006): PSP $=1$ / ([(total phosphorus - organic phosphorus $) /(5 \times$ labile phosphorus $)]+4 / 5)$. Other soil properties were derived from SSURGO data. Management information was obtained to create management input files.

The NB model was calibrated using 1993-1997 crop yields and measured water quality data (table 2 ) collected at the outlet of the Center watershed and validated using data from the West and East watersheds over the same period. The parameters adjusted through calibration included control parameters determining the choice of equations to be used for major processes (APEX control file) and global parameters quantifying process rates and thresholds values (APEX parameter file). In this study, the optimal selection of process equations was determined by a manual trial-anderror method based on model performance with default parameters (Senaviratne et al., 2013, 2014). Sensitive global parameters were then identified from a pool of over 100 parameters based on a prior study by Senaviratne et al. (2013) and the APEX user manual (Steglich and Williams, 2013). Following this determination, calibration of the most sensitive global parameters was conducted, first manually for crop yields and then with an automated tool that ranks the optimal combinations of parameter values for runoff, sediment, and TP loads using a stepwise, multi-objective, multi-variable parameter optimization method (Senaviratne et al., 2014).

Table 3. Subarea parameters used to simulate cropland, buffers, and grass waterways of the three watersheds $(\mathrm{NA}=$ not applicable).

\begin{tabular}{|c|c|c|c|c|}
\hline Parameter & Crop & $\begin{array}{c}\text { Agroforestry } \\
\text { Buffer }\end{array}$ & $\begin{array}{c}\text { Grass } \\
\text { Buffer } \\
\end{array}$ & $\begin{array}{c}\text { Grass } \\
\text { Waterway } \\
\end{array}$ \\
\hline LUN: land use number ${ }^{[\mathrm{a}]}$ & 4 & 29 & 25 & 22 \\
\hline Curve number condition II for soil group D & 88 & 77 & 79 & 80 \\
\hline $\begin{array}{l}\text { CHN, UPN, and RCHN: Manning's " } n \text { " for channel, } \\
\text { upland, and routing reach, respectively }{ }^{[\mathrm{b}]}\end{array}$ & 0.12 & 0.3 & 0.3 & 0.3 \\
\hline RCHC: USLE crop-management factor ${ }^{[b]}$ & 0.1 & 0.0001 & 0.0001 & 0.0001 \\
\hline USLE P_factor: Erosion control factor ${ }^{[b]}$ & 0.5 & 0.5 & 0.5 & 0.5 \\
\hline FFP: fraction of floodplain flow ${ }^{[\mathrm{b}]}$ & NA & 0.5 to 0.8 & 0.5 to 0.8 & NA \\
\hline RFPL: buffer/floodplain length ${ }^{[b]}$ & NA & Buffer/floodplain in km & Buffer/floodplain in km & NA \\
\hline RFPW: buffer/floodplain width ${ }^{[\mathrm{b}]}$ & NA & $\begin{array}{l}\text { (Drainage area } \times 10,000) / \\
(\text { flood plain length } \times 1000)\end{array}$ & $\begin{array}{l}(\text { Drainage area } \times 10,000) / \\
(\text { flood plain length } \times 1000)\end{array}$ & NA \\
\hline
\end{tabular}

\footnotetext{
[a] Parameter specified in the operation schedule file.

[b] Parameter specified in the subarea file (Steglich and Williams, 2013).
} 
Several model performance evaluation criteria (PEC), described by Moriasi et al. (2007), were used to compare simulated results and observed data. Crop yield assessment used simple average percent differences between simulated and measured crop yields; we used the PEC from Wang et al. (2012), which specified that simulated crop yields should be within $25 \%$ of measured yields. Model performance for flow, sediment, and TP was assessed using the coefficient of determination $\left(\mathrm{r}^{2}\right)$, Nash-Sutcliffe efficiency (NSE; Nash and Sutcliffe, 1970), and percent bias (Pbias). The PEC used in this study for event-based simulations were $r^{2} \geq 0.5$ and NSE $\geq 0.3$ for all outputs, and $|\mathrm{Pbias}| \leq 35 \%$ for runoff, $\leq 60 \%$ for sediment, and $\leq 70 \%$ for TP. These criteria were justified because of the event temporal scale of this study, which is a more refined temporal resolution than the monthly temporal scale often considered (Moriasi et al., 2015; Wang et al., 2012). These PEC are typically indicative of a model developed for planning purposes, which would be directionally accurate.

\section{Upland Buffer (UB) Model Parameterization}

The simulation of upland buffers required a second delineation in the West and Center watersheds. In order to simulate the buffers, new subareas and the channel network were redefined to include separate subareas for each buffer according to 2005 land use imagery maps downloaded for the sites. Based on this delineation, buffer areas represented $20 \%$ of the cropland area (fig. 1). In the model, fescue grass was maintained in all buffers and grass waterways, trees were also maintained in the agroforestry buffers, and annual crops were grown in the cropland. Parameters used to define each land use type were selected based on guidelines in the APEX manual and are listed in table 3. Soil properties were determined in a similar way as for the NB model, with soil cores collected in the upland buffers used to characterize buffer soils.

The upland buffer (UB) model was calibrated with edgeof-field 1998-2008 data (table 2) from the Center watershed and validated with data from the West and East watersheds over the same period. During that period, management in the West watershed, which had grass buffers, was similar to management in the Center watershed, which had agro-forestry buffers (Udawatta et al., 2011). The size and placement of buffers followed the same method; the only difference was the presence of trees in the agroforestry buffers, which APEX should be able to handle because plant growth parameters are specific to each crop. Validation on the East watershed (no buffers) was used to assess if the UB model could also handle the absence of buffers accurately. The process equations used in the model, the calibration process, and the model PEC were the same for the NB and UB models.

\section{Cross-Validation of $\mathrm{NB}$ and $\mathrm{UB}$ Models}

Following calibration of the NB and UB models, the NB model was evaluated using data from the buffer period, and the UB model was evaluated using data from the no-buffer period. Performance was assessed with the same PEC as for calibration and validation. In addition, a stepwise investigation of the parameter space was conducted for all the parameters that had different optimal values in the NB and UB models. The first step was limited to the runoff parameters and considered all possible combinations using one of the two optimal values of each parameter. Those that met the PEC were extracted and analyzed with the goal of finding combinations common to both the NB and UB models. Once a combination of common runoff parameter values was defined for both NB and UB, a similar analysis was conducted for the remaining (i.e., non-runoff) parameters that had different optimal values in the NB and UB models (second step). Results were analyzed for the compatibility and incompatibility of parameter values between the two models.

\section{ESTIMATION OF UPLAND BUFFER EFFECTIVENESS (OBJECTIVE 2)}

Adding buffers to a model that does not include any buffers involves a change in the number and shapes of the subareas that represent the topography, soil types, and management in the watershed. These changes may affect the slope lengths of the subareas in the watershed and the density and total length of the channel network used by the model. In addition, changes in vegetation and soil properties in the buffers alter evapotranspiration and infiltration. For objective 2, we determined the separate effects of buffer delineation and vegetation, as well as the full effect of buffers, and compared the latter to the effectiveness estimated from monitoring data.

\section{Effectiveness of Upland Buffer Delineation and Vegetation}

Scenario analysis with the UB model was used to differentiate the effects of shortening slope lengths and buffer vegetation on model estimates of edge-of-field transport. Three scenarios were run with the UB model:

1. No upland buffer delineation, i.e., the same watershed delineation as in the NB model but with UB model parameters.

2. Upland buffers delineated with field crops in the buffers.

3. Upland buffers delineated with agroforestry vegetation in the buffers.

Scenario 1 represents the no-buffer scenario: no buffers were delineated, subareas were defined based on soil types and topography, and crops were grown everywhere except in the grass waterway. In scenario 2 , buffer areas were delineated as individual subareas. However, they were not defined as buffers, so they were not considered floodplains and had annual crops instead of trees and grass; thus, the surface runoff coming from above was not redistributed across the subarea. In scenario 3, the buffers were defined as buffers, buffer vegetation was planted, $K_{\text {sat }}$ was adjusted for buffer conditions, and the runoff coming from above was spread across the subarea. Comparing scenarios 2 and 1 isolated the modeling effects of buffer delineation. Comparing scenarios 2 and 3 isolated the modeling effects of buffer vegetation.

All scenarios were run using the Center watershed model over the 1995-2008 simulation period. All comparisons were based on March through November values from 2004 to 2008 to facilitate comparisons with the paired watershed analysis (see below). 


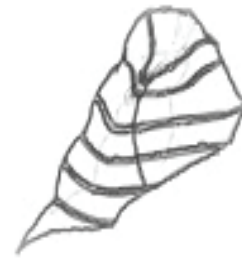

(a)

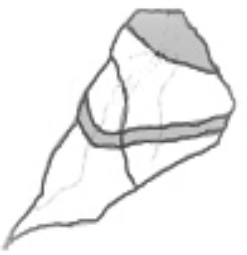

(b)

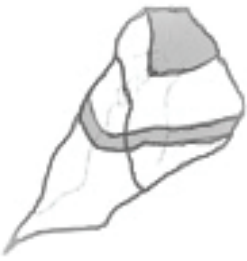

(c)

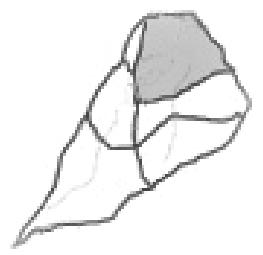

(d)

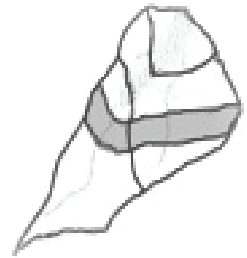

(e)

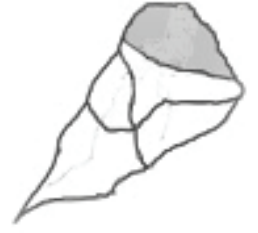

(f)

Figure 2. Different shapes, proportions, and placement of buffers used for the scenario analyses by the APEX model for the agroforestry buffer watershed at the Greenley Research Center, Missouri: (a) $20 \%$ of area as multiple upland contour buffers (actual configuration of buffers), (b) $10 \%$ as a backslope buffer strip and $10 \%$ as a flat footslope buffer, (c) $10 \%$ as a backslope buffer strip and $10 \%$ as a V-shaped footslope buffer, (d) $20 \%$ as a V-shaped footslope buffer, (e) $20 \%$ as a backslope buffer strip, and (f) $20 \%$ as a flat footslope buffer.

\section{Effectiveness of Buffers Using Simulated Paired Watershed Approach}

Udawatta et al. (2011) used a paired watershed approach to estimate upland buffer effectiveness. They used measured runoff, sediment, and P losses during the 1991-1997 period (no-buffer period) to derive relationships between losses in the Center and West watersheds compared to the control (East) watershed. They then used these relationships and the 2004-2008 monitoring data from the control watershed to estimate the response of the two upland buffer watersheds during 2004-2008 if the buffers had not been in place. Buffer effectiveness was calculated as the relative difference between this response and the 2004-2008 monitoring data in the buffer watersheds.

We followed a similar approach using APEX-simulated data instead of measured data. A regression slope (forcing a null intercept) between simulated losses in the Center and West watersheds compared to the control (East) watershed was calculated based on simulated values for the NB model for events that were monitored during the 1993-1997 period. This relationship and daily values of runoff and TP loss obtained in the control watershed with the UB model during 2004-2008 were used to calculate what would have happened if the buffers had not been in place during 2004-2008. Buffer effectiveness was calculated as the relative difference between these values and the 2004-2008 simulated daily values obtained with the UB model.

We report simulated upland buffer effectiveness for 2004-2008 based on two sets of data: (1) only the events for which monitoring data were available (to facilitate comparison with the effectiveness calculated by Udawatta et al. (2011), and (2) using all simulated daily values from March through November (to provide an annual unfrozen soil estimate).

\section{IMPaCt OF Alternative Buffer Placement ON WATER QUALITY (OBJECTIVE 3)}

A long-term (30 years) scenario analysis was conducted to investigate the effect of buffer delineation and determine the optimal type, placement, and shape of buffers representing $20 \%$ of the watersheds, i.e., the area under contour buffers according to the land use map for 2005. Buffers were grouped together to form a block representing $20 \%$ of the cropland area, or in some cases two blocks each representing $10 \%$ of the cropland area. In addition, the shape of the footslope buffers could either be V-shaped to follow the contour or flat to obtain a straight upstream boundary. All scenarios used the UB model in the Center watershed with a two-year corn-soybean rotation in the crop areas and either grass or agroforestry buffers. Effects of grass buffers were determined by eliminating the trees in the management file for the Center watershed and modifying the hydraulic conductivity in the buffers to match the values that were measured in the grass buffers of the West watershed. Figure 2 shows the subarea delineations for the following scenarios:

(a) $20 \%$ of area as multiple contour buffers (actual configuration of buffers).

(b) $10 \%$ of area as a backslope buffer strip plus $10 \%$ as a flat footslope buffer.

(c) $10 \%$ of area as a backslope buffer strip plus $10 \%$ as a Vshaped footslope buffer.

(d) $20 \%$ of area as a $\mathrm{V}$-shaped footslope buffer.

(e) $20 \%$ of area as a backslope buffer strip.

(f) $20 \%$ of area as a flat footslope buffer.

In order to isolate the buffer placement effects, the grass waterway was removed.

\section{RESULTS AND DISCUSSION \\ MODEl PARAMETERIZATION \\ Parameterization of $N B$ and $U B$ Models}

The NB and UB models simulated corn yields within $\pm 14 \%$ and soybean yields within $\pm 10 \%$ of the measured yields in the watersheds. These results are similar to those obtained by Senaviratne et al. (2013) for these watersheds prior to buffer establishment $( \pm 13 \%$ of the measured corn and soybean yields) with the previous version of APEX and well within the $25 \%$ PEC suggested by Wang et al. (2012).

The NB and UB models were both calibrated and validated for event-based runoff and TP (figs. 3 and 4), with model performance statistics well within the acceptable limits for $\mathrm{r}^{2}$, NSE, and Pbias values set for this study and the higher PEC proposed by Moriasi et al. (2015) for watershed simulation at a monthly time step. Sediment model performance indicators were acceptable only for the NB model (fig. 3). The sediment calibration with UB parameters failed to reach accepted threshold values for $\mathrm{r}^{2}$ and NSE, but Pbias values were within acceptable limits (fig. 4). Scatter plots of simulated event-based runoff, sediment, and TP versus measured values for the three watersheds during the nobuffer and upland buffer periods (figs. 3 and 4) provide a visualization of the range of measured and simulated values obtained with the optimal parameter set for the NB and UB models. 
NB model calibration in Center watershed:

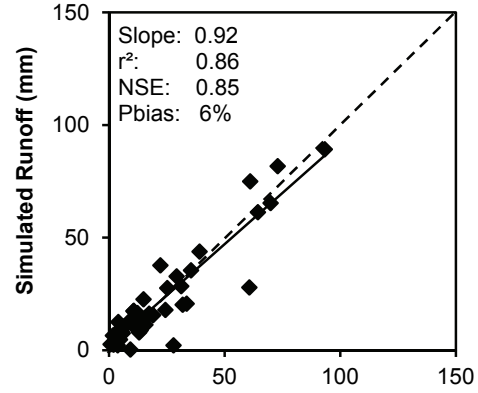

(a)

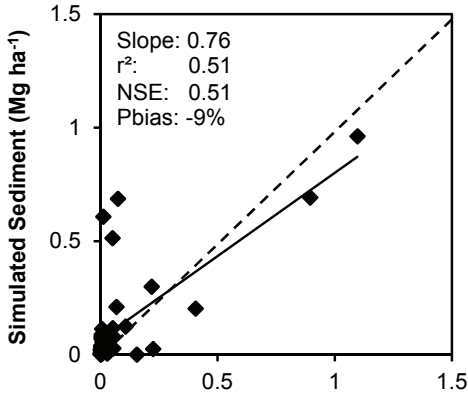

(b)

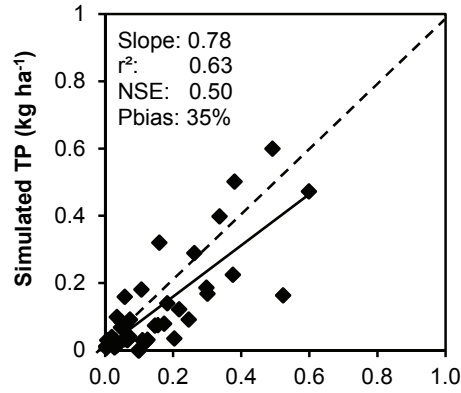

(c)

NB model validation in West watershed:

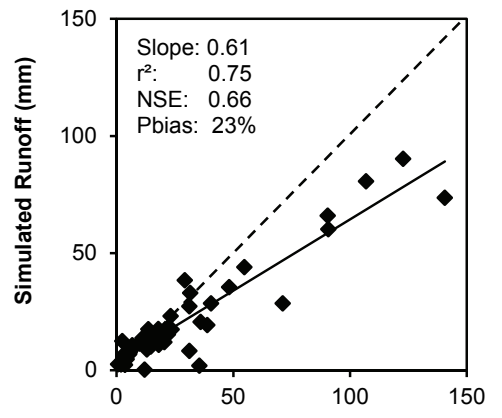

(d)

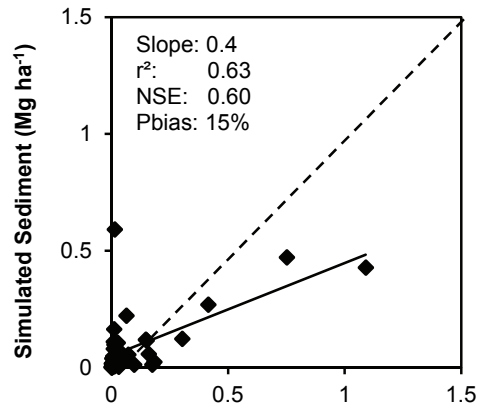

(e)

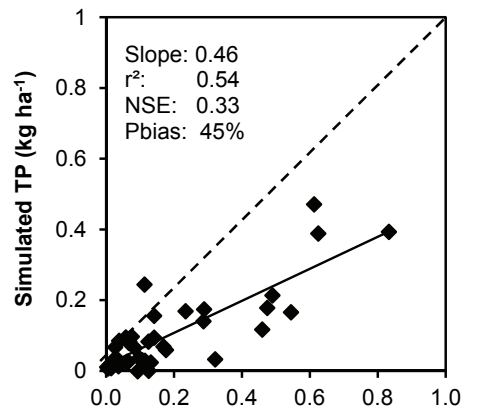

(f)

NB model validation in East watershed:

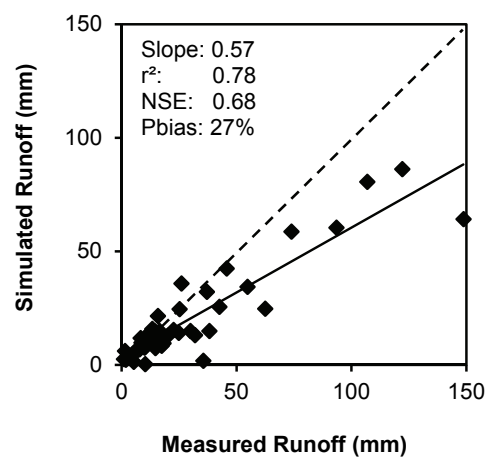

(g)

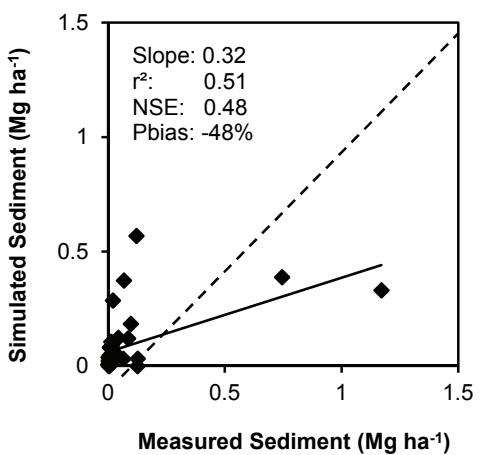

(h)

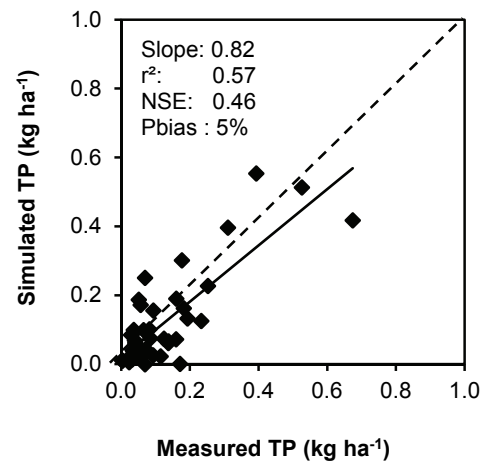

(i)

Figure 3. APEX-simulated versus measured event runoff, sediment, and total phosphorus (TP) for the no-buffer model at the Greenley Memorial Research Center (1993-1997): (a, b, and c) model calibration in Center watershed, (d, e, and f) validation in West watershed, and (h, g, and i) validation in East watershed. Each graph includes the slope and performance indicators for each simulation: coefficient of determination $\left(r^{2}\right)$, Nash-Sutcliffe efficiency (NSE), and percent bias (Pbias). The dashed line indicates the 1:1 line.

Simulated sediment event loads ( 0.00 to $\left.0.02 \mathrm{Mg} \mathrm{ha}^{-1}\right)$ during the upland buffer period were all very low and in the same range as measured event loads $\left(0.00\right.$ to $\left.0.05 \mathrm{Mg} \mathrm{ha}^{-1}\right)$, although the three largest measured loads were underpredicted (fig. 4b). Total measured sediment transport during the 11-year study period (1998-2008) was $0.29,0.22$, and $0.30 \mathrm{Mg} \mathrm{ha}^{-1}$ in the agroforestry, grass buffer, and control watersheds, respectively, which is very low. Nearing (2000) stated that soil loss measurement errors from small research plots are approximately $60 \%$ of the mean and tend to be greater for low soil loss values. Harmel et al. (2006) also associated a $7 \%$ to $53 \%$ cumulative uncertainty for measurement of sediment transport and stated that uncertainty increases with poor measurement conditions. In this study, a lack of range in event sediment loss associated with the buffer data set meant that there was insufficient information to calibrate the UB model for sediment. Given this, further sediment results will not be presented. This should not affect the TP results to a great extent because of the dominance of dissolved $\mathrm{P}$ in this low sediment loss system on poorly drained soils (Verbree et al., 2010).

\section{Cross-Validation of $N B$ and $U B$ Models}

While both models were successfully calibrated and validated for their respective runoff and TP data sets, the performance of the two models during cross-validation differed in important ways. The NB model derived through calibration with the no-buffer data did not correctly simulate $\mathrm{P}$ transport once upland buffers were established $\left(\mathrm{r}^{2}=0.38<\right.$ 


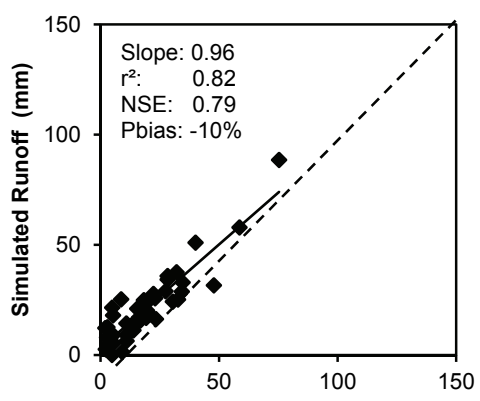

(a)

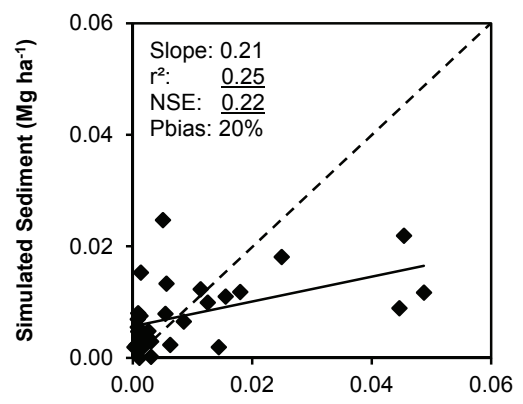

(b)

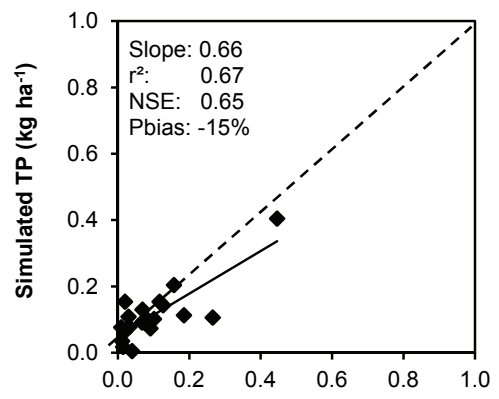

(c)

UB model validation in West watershed with grass buffer:
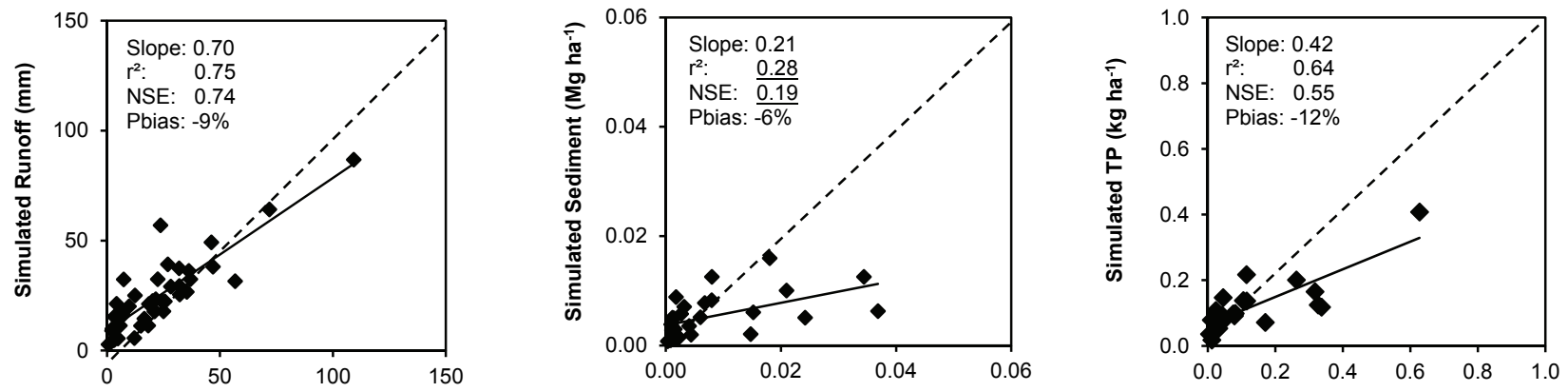

(d)

(e)

(f)

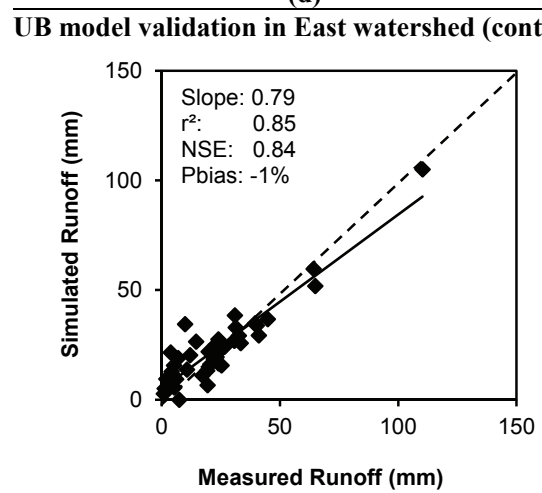

(g)

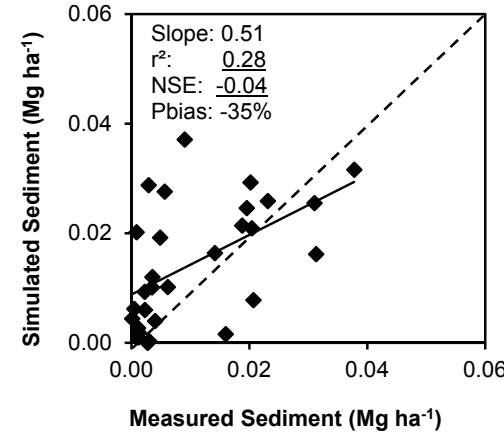

(h)

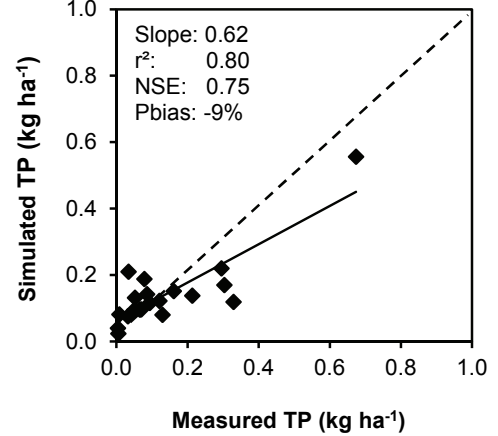

(i)

Figure 4. APEX-simulated versus measured event runoff, sediment, and total phosphorus (TP) for the upland buffer (UB) at the Greenley Memorial Research Center (1998-2008): (a, b, and c) model calibration in Center watershed, (d, e, and f) validation in West watershed, and (g, h, and i) validation in East watershed. Each graph includes the slope and performance indicators for each simulation: coefficient of determination $\left(r^{2}\right)$, Nash-Sutcliffe efficiency (NSE), and percent bias (Pbias). Underlined performance indicators did not meet minimum performance evaluation criteria (PEC). The dashed line indicates the 1:1 line.

0.50 for TP). In other words, the NB model could not satisfactorily simulate the buffer period. In contrast, the UB model was able to simulate no-buffer conditions during the buffer period and during the no-buffer period. The UB model met the PEC for the control (East) watershed for runoff and TP (figs. $4 \mathrm{~g}$ and $4 \mathrm{i}$ ) during the buffer period and for the Center watershed during the no-buffer period $\left(\mathrm{r}^{2}=0.84\right.$ and 0.60 , and NSE $=0.8$ and 0.48 for runoff and TP, respectively), indicating that a model developed for buffer conditions performed adequately for runoff and TP for a scenario with no upland buffers. The UB model did not meet the PEC for sediment during the no-buffer period, but this was expected because sediment-related parameters could not be calibrated using data from the buffer period.
Further investigation of the calibrated parameter values highlighted significant differences. While the process equations used by the NB and UB models were the same by design (table 4), calibration resulted in 16 of 23 sensitive global parameters (table 5) having different optimal values in the two models, five of them primarily affecting runoff and 11 affecting other processes. A stepwise investigation of the parameter space was conducted for these 16 parameters with each of the two optimal values for the NB and UB models, first for the five runoff parameters and then for the remaining 11 parameters. Results showed that many, but not all, of these parameters had a range of equally good values (table $6)$. Among the parameters that did not have common values for the NB and UB models, one had incompatible values 
Table 4. Key process equations used by the APEX model for the no-buffer and upland buffer models.

\begin{tabular}{cc}
\hline Process & Equation $^{[\mathrm{a}]}$ \\
\hline Runoff & $\begin{array}{c}\text { Curve number (CN) method (INFL }=0 \text { ) } \\
\end{array}$ \\
\hline Field capacity and wilting point estimation & Soil moisture index method for CN daily value estimation (NVCN $=4$ )
\end{tabular}

Table 5. Most sensitive parameters determining the rates and threshold values (parameter file) of major processes simulated in the APEX model and the values selected after calibration using data from the Center watershed located at Greenley Research Center, Knox County, Missouri, for the no-buffer (NB) and upland buffer (UB) models.

\begin{tabular}{|c|c|c|c|}
\hline APEX Parameter (Designation) ${ }^{[a]}$ & Recommended Range & NB Model & UB Model \\
\hline \multicolumn{4}{|l|}{ Runoff sensitive parameters } \\
\hline Water stress-harvest index (P3) & 0.0 to 1.0 & 0.3 & 0.5 \\
\hline Soil evaporation coefficient (P12) & 1.5 to 2.5 & 2.0 & 1.5 \\
\hline $\mathrm{CN}$ residue adjustment parameter $(\mathrm{P} 15)$ & 0.0 to 0.3 & 0.02 & 0.0 \\
\hline Soil evaporation and plant cover factor (P17) & 0.00 to 0.5 & 0.1 & 0.1 \\
\hline $\mathrm{CN}$ initial abstraction $(\mathrm{P} 20)$ & 0.05 to 0.4 & 0.2 & 0.2 \\
\hline $\mathrm{CN}$ index coefficient $(\mathrm{P} 42)$ & 0.3 to 2.5 & 2.0 & 2.5 \\
\hline Upper limit of $\mathrm{CN}$ retention parameter (P44) & 1.0 to 2.0 & 2.0 & 1.5 \\
\hline Subsurface flow factor (P90) & 1.0 to 100.0 & 2.0 & 2.0 \\
\hline \multicolumn{4}{|l|}{ Sediment sensitive parameters } \\
\hline Sediment routing coefficient (P19) & 0.01 to 0.05 & 0.02 & 0.01 \\
\hline Exponential coefficient used to account for rainfall intensity on $\mathrm{CN}$ (P25) & 0.0 to 2.0 & 0.0 & 0.5 \\
\hline RUSLE C-factor coefficient in residue function (P46) & 0.5 to 1.5 & 0.5 & 1.0 \\
\hline RUSLE C-factor coefficient (P47) & 0.5 to 1.5 & 1.0 & 1.5 \\
\hline Water stored in litter (residue) coefficient (P51) & 0.1 to 0.9 & 0.0 & 0.7 \\
\hline Standing dead fall rate coefficient (P76) & 0.0001 to 0.01 & 0.0001 & 0.0001 \\
\hline \multicolumn{4}{|l|}{ Biological activity sensitive parameters } \\
\hline Biological mixing efficiency (P29) & 0.1 to 0.5 & 0.5 & 0.5 \\
\hline Maximum depth for biological mixing (P31) & 0.1 to 0.3 & 0.3 & 0.3 \\
\hline Coefficient adjusts microbial activity function in the top soil layer (P69) & 0.1 to 1.0 & 0.6 & 0.4 \\
\hline Microbial decay rate coefficient (P70) & 0.5 to 1.5 & 0.7 & 0.5 \\
\hline \multicolumn{4}{|l|}{ TP sensitive parameters } \\
\hline Soluble phosphorus runoff coefficient (P8) & 10 to 20 & 14 & 14 \\
\hline $\mathrm{P}$ enrichment ratio exponent for routing ( $\mathrm{P} 58)$ & 0.3 to 0.9 & 0.6 & 0.9 \\
\hline $\mathrm{P}$ upward movement by evaporation coefficient (P59) & 1 to 20 & 1.0 & 3.0 \\
\hline Coefficient regulating P flux between labile and active pool (P84) & 0.0001 to 0.6 & 0.6 & 0.3 \\
\hline \multicolumn{4}{|l|}{ TN sensitive parameters } \\
\hline Volatilization/nitrification partitioning coefficient (P72) & 0.05 to 0.5 & 0.15 & 0.05 \\
\hline
\end{tabular}

[a] $\mathrm{CN}=$ curve number, $\mathrm{TP}=$ total phosphorus, and $\mathrm{TN}=$ total nitrogen.

Table 6. Range of good parameter values for the 16 parameters that had different optimal values in the no-buffer (NB) and upland buffer (UB) models of the Center watershed at Greenley Research Center, Knox County, Missouri. Parameters for which the ranges do not coincide between the two models are shown in bold.

\begin{tabular}{|c|c|c|}
\hline APEX Parameter (Designation) ${ }^{[a]}$ & NB Model & UB Model \\
\hline \multicolumn{3}{|l|}{ Runoff sensitive parameters } \\
\hline Water stress-harvest index $(\mathrm{P} 3)$ & 0.3 to 0.5 & 0.3 to 0.5 \\
\hline Soil evaporation coefficient (P12) & 1.5 to 2.0 & 1.5 to 2.0 \\
\hline $\mathrm{CN}$ residue adjustment parameter $(\mathrm{P} 15)$ & 0.00 to 0.02 & 0.0 \\
\hline $\mathrm{CN}$ index coefficient $(\mathrm{P} 42)$ & 2.0 to 2.5 & 2.0 to 2.5 \\
\hline Upper limit of $\mathrm{CN}$ retention parameter $(\mathrm{P} 44)$ & 1.5 to 2.0 & 1.5 to 2.0 \\
\hline \multicolumn{3}{|l|}{ Sediment sensitive parameters } \\
\hline Sediment routing coefficient (P19) & 0.01 to 0.02 & 0.01 to 0.02 \\
\hline Exponential coefficient used to account for rainfall intensity on $\mathrm{CN}$ (P25) & 0.0 to 0.5 & 0.0 to 0.5 \\
\hline RUSLE C-factor coefficient in residue function (P46) & 0.5 & 1.0 \\
\hline RUSLE C-factor coefficient (P47) & 1.0 to 1.5 & 1.0 to 1.5 \\
\hline Water stored in litter (residue) coefficient (P51) & 0.0 to 0.7 & 0.0 to 0.7 \\
\hline \multicolumn{3}{|l|}{ Biological activity sensitive parameters } \\
\hline Coefficient adjusts microbial activity function in the top soil layer (P69) & 0.4 to 0.6 & 0.4 \\
\hline Microbial decay rate coefficient $(\mathbf{P} 70)$ & 0.5 to 0.7 & 0.5 \\
\hline \multicolumn{3}{|l|}{ TP sensitive parameters } \\
\hline $\mathrm{P}$ enrichment ratio exponent for routing (P58) & 0.6 to 0.9 & 0.6 to 0.9 \\
\hline P upward movement by evaporation coefficient (P59) & 1.0 to 3.0 & 1.0 to 3.0 \\
\hline Coefficient regulating P flux between labile and active pool (P84) & 0.3 to 0.6 & 0.3 to 0.6 \\
\hline \multicolumn{3}{|l|}{ TN sensitive parameters } \\
\hline Volatilization/nitrification partitioning coefficient (P72) & 0.05 to 0.15 & 0.05 to 0.15 \\
\hline
\end{tabular}


(P46), and three were constrained to one possible value in the buffer conditions while they had a larger range of values in the NB model (P15, P69, P70). Interestingly, these four parameters were related to residues, and the differences may have been caused by the presence of different kinds of residues in the buffers. Alternatively, we must keep in mind that no-till had been practiced for seven years prior to the buffer period but for only two years prior to the no-buffer period. This longer implementation of no-till may have changed the residue cover on the cropland part of the watersheds. Whatever the case may be, i.e., longer no-till implementation or land cover in the buffers, the result demonstrates that simulation of management practices has impacts on global model input parameters beyond those listed in the guidelines to represent these practices (e.g., Waidler et al., 2011). Better understanding of how management practices affect these parameters is desirable for more accuracy in the estimation of practice effectiveness. Bhandari et al. (2017) arrived at a similar conclusion and recommended using calibration data that cover both practice and no-practice scenarios.

\section{EFFECTIVENESS OF UPLAND BUFFERS Effectiveness of Upland Buffer Delineation and Vegetation}

A scenario analysis was used to differentiate the impact of upland delineation from that of buffer vegetation with the UB model on reductions in runoff and TP from upland agroforesty buffers in the Center watershed. Scenarios results showed that the change from no buffer delineation (scenario 1) to upland buffer delineation (scenario 2) resulted in $14 \%$ and $12 \%$ reductions in estimated water yield and TP, respectively (delta 1-2; table 7). This delineation effect was as large as the effect of buffer vegetation on runoff and twothirds of the effect of buffer vegetation on TP (delta 2-3; table 7). Sediment loss was not included in the analysis because the PEC were not met for sediment for the UB model. In addition, we did not use the NB model because, as previously noted, it failed the PEC when validated with data from the upland buffer period.

In addition to increasing the spatial variability of model inputs, a finer discretization (more subareas) increases the total length of channels being simulated, which affects the processes that take place during channel routing (Baffaut et al., 1997; Cho et al., 2010; Her et al., 2015). Infiltration occurs in the floodplain area on either side of the channel. Sediment deposition occurs if the transport capacity is less than the incoming sediment load; if flow velocities create excess transport capacity, channel degradation occurs. Thus, channel routing affects water infiltration and sediment transport, as well as dissolved and sediment-bound nutrients. Channel length is therefore critical to $\mathrm{P}$ transport because of these processes. This explains why delineation alone caused $12 \%$ to $14 \%$ reduction in simulated runoff and $\mathrm{P}$ transport (table 7). Analysis of measured hydrographs at a sub-daily resolution might provide information on the buffer effects on time of concentration and flow routing and thus on the appropriate delineation, but that level of analysis was beyond the scope of this study. These results show that delineation decisions, which have impacts on flow and $\mathrm{P}$ routing and $\mathrm{ul}-$ timately on $\mathrm{P}$ transport estimates, are a critical component of the estimated benefits of buffer practices. Thus, it would be erroneous to estimate effectiveness by only comparing the water quality impacts of perennial vegetation and annual crops in the buffers. Regarding the buffer vegetation, the success of the upgraded code to document treatment differences where the old code failed supports the value of this code change for simulating the effects of buffers on edge-offield runoff and TP. However, we did not have any bufferlevel data to confirm the accuracy of the simulated vegetation effect.

\section{Buffer Effectiveness Using Simulated Paired Watershed Approach}

Reductions of runoff and TP by agroforestry buffers calculated using the simulated paired watershed approach for monitored events (table 8) were within three percentage points of the results obtained with measured edge-of-field data for runoff and TP. For the grass buffers, the reductions calculated with measured and simulated data were farther apart for runoff (eight percentage points) but still close for TP (one percentage point). Results using all simulated March-November daily values from 2004 to 2008 (table 8) were in the same range.

The simulated paired watershed approach required two model calibrations with datasets covering the no-buffer and upland buffer periods. However, a model is most advantageous if it can be calibrated with one dataset, followed by

Table 7. Percent differences in total March-November 2004-2008 water yield and total phosphorus losses obtained for three scenarios with the upland buffer model.

\begin{tabular}{|c|c|c|c|c|c|}
\hline \multirow[b]{2}{*}{ Scenario } & \multirow[b]{2}{*}{ Scenario Name } & \multicolumn{2}{|c|}{ Water Yield } & \multicolumn{2}{|c|}{ Total Phosphorus } \\
\hline & & $\mathrm{Mm}$ & Reduction & $\mathrm{kg} \mathrm{ha}^{-1}$ & Reduction \\
\hline 1 & No buffer delineation & 1343 & - & 6.96 & - \\
\hline 2 & Buffer delineated with crops in the buffers & 1152 & - & 6.14 & - \\
\hline 3 & Buffer delineated with agroforestry in buffers & 1010 & - & 5.04 & - \\
\hline & Delta 1-2: buffer delineation effect & 191 & $14 \%$ & 0.82 & $12 \%$ \\
\hline & Delta 2-3: buffer vegetation effect & 142 & $12 \%$ & 1.10 & $18 \%$ \\
\hline & Delta 1-3: total effect & 333 & $25 \%$ & 1.92 & $28 \%$ \\
\hline
\end{tabular}

Table 8. Estimated buffer effectiveness using paired watershed approach with three different data sets for agroforestry and grass buffers.

\begin{tabular}{|c|c|c|c|}
\hline & & Runoff & $\mathrm{TP}$ \\
\hline \multirow[t]{3}{*}{ Agroforestry buffers } & Udawatta et al. (2011), based on comparison of 2004-2008 monitored events & $-15 \%$ & $-26 \%$ \\
\hline & Based on comparison of APEX-simulated values for 2004-2008 monitored events & $-18 \%$ & $-29 \%$ \\
\hline & Based on comparison of March-November 2004-2008 APEX-simulated daily values & $-23 \%$ & $-30 \%$ \\
\hline \multirow[t]{3}{*}{ Grass buffers } & Udawatta et al. (2011), based on comparison of 2004-2008 monitored events & $-23 \%$ & $-22 \%$ \\
\hline & Based on comparison of APEX-simulated values for 2004-2008 monitored events & $-15 \%$ & $-21 \%$ \\
\hline & Based on comparison of March-November 2004-2008 APEX-simulated daily values & $-16 \%$ & $-19 \%$ \\
\hline
\end{tabular}


assessing the effectiveness of buffers by adding or removing them. Reduction rates based on March-November 20042008 daily values should be the same when calculated with the paired watershed approach (table 8 ) or by adding buffers with different vegetation (table 7). The $23 \%$ and $30 \%$ reductions in runoff and $\mathrm{TP}$, respectively, in the agroforestry watershed based on all March-November simulated daily values (table 8) were close to the total effect with the UB model ( $25 \%$ and $28 \%$, respectively; table 7 ). On the other hand, the reductions estimated with the NB model (not shown) were farther apart (30\% and 39\%, respectively), which emphasizes the need for a model that performs well with and without the practice being evaluated (Bhandari et al., 2017).

Discharge measurement methods with a flow-control structure but without periodic discharge checks typically yield measurement errors of $5 \%$ to $10 \%$ (Harmel et al., 2006). Errors in TP transport typically range from $8 \%$ to $110 \%$ when measured by analysis of samples collected at regular flow intervals (Harmel et al., 2006). In addition, although uncertainty analysis was beyond the scope of this study, uncertainty of simulation results caused by parameter uncertainty is often within $10 \%$ for runoff and greater for TP. For example, Moriasi et al. (2016) determined the uncertainty of APEX-simulated annual runoff to be $\pm 3 \%$ for a small watershed in Ohio. Bolster et al. (2014) estimated the uncertainty of $\mathrm{P}$ predictions by the Annual P Loss Estimator (APLE) model (Vadas et al., 2009) to be within 28\% for a high uncertainty of input parameters. Thus, the differences between buffer effectiveness calculated with measured or simulated data (up to $8 \%$ for runoff and $3 \%$ for TP) were within the same range as or smaller than common uncertainty ranges associated with measured data and modeling results.

According to Seobi et al. (2005), although the $K_{\text {sat }}$ values in the grass and agroforestry buffers at this research site remained relatively small (i.e., 26 to $30 \mathrm{~mm} \mathrm{~h}^{-1}$ ), they were 1.5 times greater than in the cropland area, with even greater gains in the restrictive layer. Water quality impacts reported for management systems on claypan soils are often related to the very low infiltration rates (i.e., 0.001 to $0.01 \mathrm{~mm} \mathrm{~h}^{-1}$ ) in the restrictive layer, which cause excessive runoff and associated transport of pollutants. The results of this study support the contention that these low, but greater than the crop area, infiltration rates in the buffers were capable of reducing the runoff and TP export documented by Udawatta et al. (2011) from measured data analysis. Thus, buffers may be an important tool for reducing $\mathrm{P}$ transport on these soils.

\section{EFFECTIVENESS OF AlTERNATIVE \\ BufFer Placement}

The results of the scenario analysis for alternative buffer placements showed that long-term average annual predictions for runoff and TP were lowest for the split placement of agroforestry buffers with $10 \%$ at the backslope $(\sim 22 \mathrm{~m}$ wide) and $10 \%$ at the footslope ( 30 to $40 \mathrm{~m}$ wide). The simulated percent reductions in annual runoff and TP from agroforestry buffers were $14 \%$ to $15 \%$ and $21 \%$ to $22 \%$, respectively, for the split placement compared to the no-buffer scenario (fig. 5). The placement of agroforestry buffers as multiple upland contour buffers or as a $20 \%$ buffer at the footslope or backslope (50 to $70 \mathrm{~m}$ wide) were less efficient than split placement, with reductions ranging from $9 \%$ to $11 \%$ for average annual runoff and from $12 \%$ to $16 \%$ for TP losses. The simulated buffer effectiveness for grass buffers did not show the same trend. All the grass buffer placement alternatives were equivalent, with annual runoff reductions ranging from $6 \%$ to $10 \%$ and annual TP reductions ranging from $8 \%$ to $12 \%$ compared to the no-buffer scenario. Model predictions for grass buffers for different placements generally demonstrated lower effectiveness than agroforestry buffers for both runoff and TP loads. The shape of the buffer (either flat or V-shaped) showed no impact on buffer effectiveness in model-simulated runoff and TP losses.

The purpose of buffers is to slow flow velocity, thereby allowing time for water to infiltrate and then percolate into the soil profile while sediment and other suspended particles

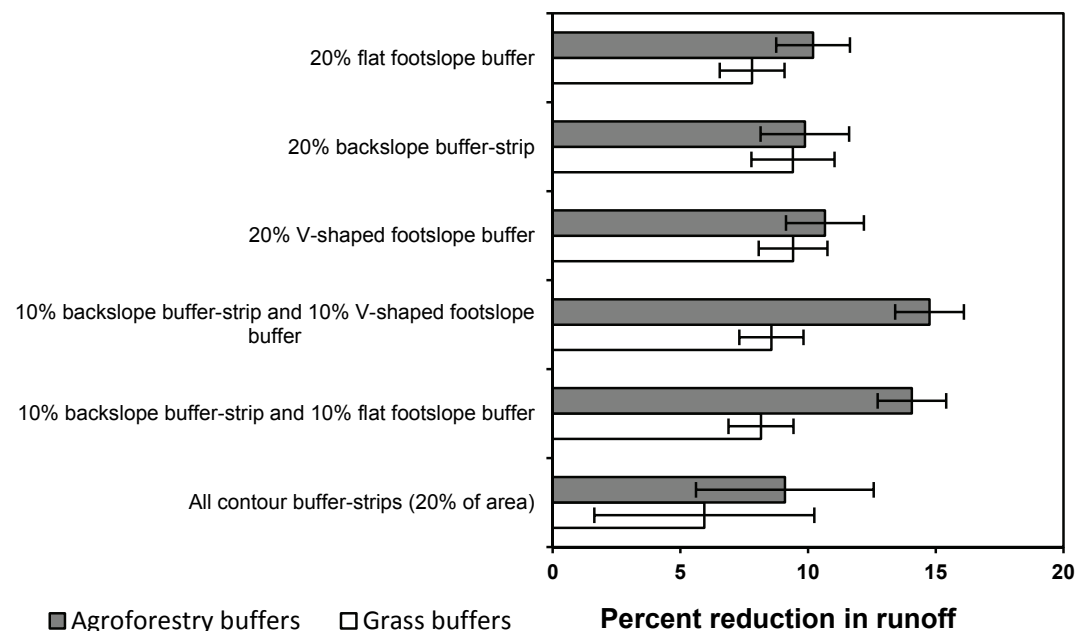

(a)

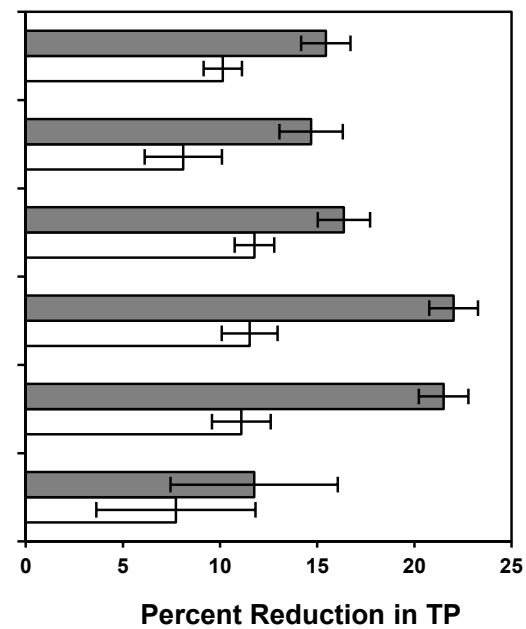

(b)

Figure 5. Average percent reductions in (a) annual runoff and (b) total phosphorus (TP) losses relative to the no-buffer scenario as predicted by the APEX model for different placements of agroforestry and grass buffers in the Center watershed at Greenley Memorial Research Center, Missouri. Whiskers represent standard errors of annual values over 30 years. 
settle out (Liu et al., 2008). Schueler (1987) suggested that for adequate buffer infiltration, $K_{\text {sat }}$ values of soils should at least range from 69 to $127 \mathrm{~mm} \mathrm{~h}^{-1}$. Overall low simulated buffer effectiveness by any type of buffer configuration, compared to reported values (82\%; Helmers et al., 2012), may be attributed to low infiltration rates as a result of low $K_{\text {sat }}$ values of soils for both types of buffers: 16 to $32 \mathrm{~mm}$ $\mathrm{h}^{-1}$ and 1 to $13 \mathrm{~mm} \mathrm{~h}^{-1}$ in agroforestry and grass buffers, respectively (Seobi et al., 2005). Indeed, a recent experiment on claypan soils led to $19 \%$ to $28 \%$ buffer effectiveness for trapping herbicide loads with varying adsorption coefficients and for varying buffer widths (Lerch et al., 2017). Herbicide and phosphorus are comparable in movement and are simulated with similar equations, although they are characterized by different adsorption coefficients (Neitsch et al., 2011; Williams et al., 2012). In addition, in a review of 80 articles, Liu et al. (2008) revealed that buffer effectiveness varies with buffer width, slope, area ratio, rainfall, and vegetation, but they emphasized that buffer slope and width were the most influential factors. Their findings indicated that a $10 \mathrm{~m}$ buffer at $9 \%$ slope proved to be most effective. Other studies have reported different optimal combinations of width and slope for buffers: 4 to 4.5 m optimum width for $2 \%$ to $9 \%$ slopes (Robinson et al., 1996), $7.5 \mathrm{~m}$ width for $6.5 \%$ slopes (Schmitt et al., 1999), and $20 \mathrm{~m}$ width for $10 \%$ slopes (Zhang et al., 2010). The reported optimum buffer widths vary widely depending on the prevailing conditions, and the results of the current study are applicable only to regions with similar soils and landscape conditions.

\section{CONCLUSION}

The APEX code modifications to specify floodplain $K_{\text {sat }}$ values at the subarea level, instead of a common value for the whole watershed, allowed simulation of edge-of-field runoff and TP in field-size watersheds with upland buffers. While the ranges of input parameter values led to acceptable performance for most parameters with and without buffers, some parameters had a more restricted range for the buffer conditions than for the no-buffer conditions, and one sediment-related parameter had incompatible values between the buffer and no-buffer conditions.

Buffer effectiveness in controlling runoff and $\mathrm{P}$ export, as estimated by removing the buffers from the UB model or with a simulated paired watershed approach using APEX values simulated with the UB and NB models, was similar to that estimated with monitoring data. Adding buffers to the NB model, whose performance was not acceptable when buffers were simulated, led to overestimated effectiveness. Alteration of the channel network and vegetation in the buffers both contributed to the full impact of the buffers, and simulating the no-buffer conditions by planting annual crops in the buffer areas did not produce the expected effectiveness, emphasizing the role of subarea delineation in the model.

The scenario analysis implied that upland contour buffers with agroforestry vegetation were not necessarily the most effective strategy for reducing edge-of-field runoff and TP loss, with similar or better outcomes achieved using two wider buffers placed at the backslope and footslope positions in the landscape. This suggests that conservation planners have flexibility in working with farmers on the placement of buffers. These results confirm the utility of APEX for extending measured data to facilitate assessment of structural conservation practices such as upland buffers and to generate the long-term estimates needed to evaluate the value of conservation practices. However, this research also documents the complexity of successfully simulating structural practices such as upland contour buffers.

\section{ACKNOWLEDGEMENTS}

This project was funded by the University of Missouri Center for Agroforestry under Cooperative Agreement 586227-1-004 with the USDA-ARS. Data analysis and model simulation work were partly funded by the USDA-NRCS Conservation Innovation Grant "to validate, improve, and regionalize phosphorus indices to reduce phosphorous $(\mathrm{P})$ loads across the Heartland region."

\section{REFERENCES}

Al-wadaey, A., Wortmann, C. S., Franti, T. G., Shapiro, C. A., \& Eisenhauer, D. E. (2012). Effectiveness of grass filters in reducing phosphorus and sediment runoff. Water Air Soil Pollution, 223(9), 5865-5875. https://doi.org/10.1007/s11270012-1322-2

Arabi, M., Frankenberger, J. R., Engel, B. A., \& Arnold, J. G. (2008). Representation of agricultural conservation practices with SWAT. Hydrol. Proc., 22(16), 3042-3055. https://doi.org/10.1002/hyp.6890

Baffaut, C., Nearing, M. A., Ascough II, J. C., \& Liu, B. Y. (1997). The WEPP watershed model: II. Sensitivity analysis and discretization on small watersheds. Trans. ASAE, 40(4), 935943. https://doi.org/10.13031/2013.21344

Bhandari, A. B., Nelson, N. O., Sweeney, D. W., Baffaut, C., Lory, J. A., Senaviratne, A., ... Barnes, P. L. (2017). Calibration of the APEX model to simulate management practice effects on runoff, sediment, and phosphorus loss. J. Environ. Qual., 46(6), 13321340. https://doi.org/10.2134/jeq2016.07.0272

Bhattarai, R., Kalita, P. K., \& Patel, M. K. (2009). Nutrient transport through a vegetative filter strip with subsurface drainage. J. Environ. Mgmt., 90(5), 1868-1876. https://doi.org/10.1016/j.jenvman.2008.12.010

Blanco-Canqui, H., Gantzer, C. J., Anderson, S. H., \& Alberts, E. E. (2004). Grass barriers for reduced concentrated flow induced soil and nutrient loss. SSSA J., 68(6), 1963-1972. https://doi.org/10.2136/sssaj2004.1963

Bolster, C. H., \& Vadas, P. A. (2014). Sensitivity and uncertainty analysis for the Annual Phosphorus Loss Estimator model. $J$. Environ. Qual., 42(4), 1109-1118. https://doi.org/10.2134/jeq2012.0418

Caron, E., Lafrance, P., Auclair, J.-C., \& Duchemin, M. (2010). Impact of grass and grass with poplar buffer strips on atrazine and metolachlor losses in surface runoff and subsurface infiltration from agricultural plots. J. Environ. Qual., 39(2), 617629. https://doi.org/10.2134/jeq2009.0041

Cho, J., Vellidis, G., Bosch, D. D., Lowrance, R., \& Strickland, T. (2010). Water quality effects of simulated conservation practice scenarios in the Little River Experimental watershed. J. Soil Water Cons., 65(6), 463-473. https://doi.org/10.2489/jswc.65.6.463

Daniels, R. B., \& Gilliam, J. W. (1996). Sediment and chemical load reduction by grass and riparian filters. SSSA J., 60(1), 246- 
251.

https://doi.org/10.2136/sssaj1996.03615995006000010037x

Dillaha, T. A., Reneau, R. B., Mostaghimi, S., \& Lee, D. (1989).

Vegetative filter strips for agricultural nonpoint-source pollution control. Trans. ASAE, 32(2), 513-519.

https://doi.org/10.13031/2013.31033

Gassman, P. W., Williams, J. R., Wang, X., Saleh, A., Osei, E., Hauck, L. M., ... Flowers, J. D. (2010). Invited review article: The Agricultural Policy/Environmental eXtender (APEX) model: An emerging tool for landscape and watershed environmental analyses. Trans. ASABE, 53(3), 711-740. https://doi.org/10.13031/2013.30078

Gumiere, S. J., Le Bissonnais, Y., Raclot, D., \& Cheviron, B. (2011). Vegetated filter effects on sedimentological connectivity of agricultural catchments in erosion modelling: A review. Earth Surf. Proc. Landforms, 36(1), 3-19. https://doi.org/10.1002/esp.2042

Harmel, R. D., Cooper, R. J., Slade, R. M., Haney, R. L., \& Arnold, J. G. (2006). Cumulative uncertainty in measured streamflow and water quality data for small watersheds. Trans. ASABE, 49(3), 689-701. https://doi.org/10.13031/2013.20488

Haverkamp, S., Srinivasan, R., Frede, H. G., \& Santhi, C. (2002). Subwatershed spatial analysis tool: Discretization of a distributed hydrologic model by statistical criteria. JAWRA, 38(6), 1723-1733. https://doi.org/10.1111/j.17521688.2002.tb04377.x

Helmers, M. J., Isenhart, T. M., Dosskey, M. G., Dabney, S. M., \& Strock, J. S. (2008). Buffers and vegetative filter strips. Paper 20. USDA Forest Service/UNL Faculty Publ. Retrieved from http://digitalcommons.unl.edu/usdafsfacpub/20/

Helmers, M. J., Zhou, X., Asbjornsen, H., Kolka, R., Tomer, M. D., \& Cruse, R. M. (2012). Sediment removal by prairie filter strips in row-cropped ephemeral watersheds. J. Environ. Qual., 41(5), 1531-1539. https://doi.org/10.2134/jeq2011.0473

Her, Y., Frankenberger, J., Chaubey, I., \& Srinivasan, R. (2015). Threshold effects in HRU definition ofthe soil and water assessment tool. Trans. ASABE, 58(2), 367-378. https://doi.org/10.13031/trans.58.10805

Kumar, S., Anderson, S. H., Udawatta, R. P., \& Kallenbach, R. L. (2012). Water infiltration influenced by agroforestry and grass buffers for a grazed pasture system. Agroforestry Syst., 84(3), 325-335. https://doi.org/10.1007/s10457-011-9474-4

Kumar, S., Udawatta, R. P., Anderson, S. H., \& Mudgal, A. (2011). APEX model simulation of runoff and sediment losses for grazed pasture watersheds with agroforestry buffers. Agroforestry Syst., 83(1), 51-62. https://doi.org/10.1007/s10457010-9350-7

Larson, R. A., \& Safferman, S. I. (2012). Field application of farmstead runoff to vegetated filter strips: Surface and subsurface water quality assessment. J. Environ. Qual., 41(2), 592-603. https://doi.org/10.2134/jeq2011.0125

Lee, K.-H., Isenhart, T. M., Schultz, R. C., \& Mickelson, S. K. (2000). Multispecies riparian buffers trap sediment and nutrients during rainfall simulations. J. Environ. Qual., 29(4), 1200-1205. https://doi.org/10.2134/jeq2000.00472425002900040025x

Lerch, R. N., Lin, C. H., Goyne, K. W., Kremer, R. J., \& Anderson, S. H. (2017). Vegetative buffer strips for reducing herbicide transport in runoff: Effects of buffer width, vegetation, and season. JAWRA, 53(3), 667-683. https://doi.org/10.1111/17521688.12526

Lin, C. H., Lerch, R. N., Garrett, H. E., \& George, M. F. (2008). Bioremediation of atrazine-contaminated soil by forage grasses: Transformation, uptake, and detoxification. J. Environ. Qual., 37(1), 196-206. https://doi.org/10.2134/jeq2006.0503

Liu, X., Zhang, X., \& Zhang, M. (2008). Major factors influencing the efficacy of vegetated buffers on sediment trapping: A review and analysis. J. Environ. Qual., 37(5), 1667-1674.

https://doi.org/10.2134/jeq2007.0437

Lowrance, R., Todd, R., Fail Jr., J., Hendrickson Jr., O., Leonard, R., \& Asmussen, L. (1984). Riparian forests as nutrient filters in agricultural watersheds. BioScience, 34(6), 374-377. https://doi.org/10.2307/1309729

Mallarino, A. P., \& Atia, A. M. (2005). Correlation of a resin membrane soil phosphorus test with corn yield and routine soil tests. SSSA J., 69(1), 266-272. https://doi.org/10.2136/sssaj2005.0266

Mayer, L. D., Dabney, S. M., \& Kemper, W. D. (1999). Designing research to improve runoff and erosion control practices example, grass hedges. Proc. 10th Intl. Soil Conservation Meeting (pp. 447-451). Purdue University, USDA-ARS National Erosion Laboratory.

Miles, R. J., \& Hammer, R. D. (1989). One hundred years of Sanborn field: Soil baseline data. In J. R. Brown (Ed.), Proc. Sanborn Field Centennial (pp. 100-108). Columbia, MO: University of Missouri.

Moriasi, D. N., Arnold, J. G., Van Liew, M. W., Bingner, R. L., Harmel, R. D., \& Veith, T. L. (2007). Model evaluation guidelines for systematic quantification of accuracy in watershed simulations. Trans. ASABE, 50(3), 885-900.

https://doi.org/10.13031/2013.23153

Moriasi, D. N., Gitau, M. W., Pai, N., \& Daggupati, P. (2015). Hydrologic and water quality models: Performance measures and evaluation criteria. Trans. ASABE, 58(6), 1763-1785. https://doi.org/10.13031/trans.58.10715

Moriasi, D. N., King, K. W., Bosch, D. D., Bjorneberg, D. L., Teet, S., Guzman, J. A., \& Williams, M. R. (2016). Framework to parameterize and validate APEX to support deployment of the nutrient tracking tool. Agric. Water Mgmt., 177, 146-164. https://doi.org/10.1016/j.agwat.2016.07.009

Mudgal, A., Baffaut, C., Anderson, S. H., Sadler, E. J., Kitchen, N. R., Sudduth, K. A., \& Lerch, R. N. (2012). Using the Agricultural Policy/Environmental eXtender to develop and validate physically based indices for the delineation of critical management areas. J. Soil Water Cons., 67(4), 284-299. https://doi.org/10.2489/jswc.67.4.284

Muleta, M., Nicklow, J. W., \& Bekele, E. G. (2007). Sensitivity of a distributed watershed simulation model to spatial scale. $J$. Hydrol. Eng., 12(2), 163-172. https://doi.org/10.1061/(ASCE)1084-0699(2007)12:2(163)

Nash, J. E., \& Sutcliffe, J. V. (1970). River flow forecasting through conceptual models part I: A discussion of principles. J. Hydrol., 10(3), 282-290. https://doi.org/10.1016/0022-1694(70)90255-6

Nathan, M. V., Stecker, J. A., \& Sun, Y. (2012). Soil testing in Missouri: A guide for conducting soil tests in Missouri. Publication EC923. Columbia, MO: University of Missouri Extension. Retrieved from http://soilplantlab.missouri.edu/soil/ec923.pdf

Nearing, M. A. (2000). Evaluating soil erosion models using measured plot data: Accounting for variability in the data. Earth Surf. Proc. Landforms, 25(9), 1035-1043. https://doi.org/10.1002/1096-9837(200008)25:9<1035::AIDESP121>3.0.CO;2-B

Neitsch, S. L., Arnold, J. G., Kiniry, J. R., \& Williams, J. R. (2011). Soil and Water Assessment Tool: Theoretical documentation version 2009. TR-406-11. College Station, TX: Texas Water Resources Institute.

Nelson, N. O., \& Parsons, J. E. (2006). Modification and validation of GLEAMS for prediction of phosphorus leaching in wasteamended soils. Trans. ASABE, 49(5), 1395-1407. https://doi.org/10.13031/2013.22055

Robinson, C. A., Ghaffarzadeh, M., \& Cruse, R. M. (1996). Vegetative filter strip effects on sediment concentration in 
cropland runoff. J. Soil Water Cons., 51(3), 227-230.

Santhi, C., Kannan, N., White, M., Di Luzio, M., Arnold, J. G., Wang, X., \& Williams, J. R. (2014). An integrated modeling approach for estimating the water quality benefits of conservation practices at the river basin scale. J. Environ. Qual., 43(1), 177-198. https://doi.org/10.2134/jeq2011.0460

Schmitt, T. J., Dosskey, M. G., \& Hoagland, K. D. (1999). Filter strip performance and processes for different vegetation, widths, and contaminants. J. Environ. Qual., 28(5), 1479-1489. https://doi.org/10.2134/jeq1999.00472425002800050013x

Schueler, T. R. (1987). Controlling urban runoff: A practical manual for planning and designing urban BMPs. Washington, DC: Metropolitan Washington Council of Governments.

Senaviratne, A. G. M. M. M., Udawatta, R. P., Baffaut, C., \& Anderson, S. H. (2013). Agricultural Policy Environmental eXtender simulation of three adjacent row-crop watersheds in the claypan region. J. Environ. Qual., 42(3), 726-736. https://doi.org/10.2134/jeq2012.0241

Senaviratne, A. G. M. M. M., Udawatta, R. P., Baffaut, C., \& Anderson, S. H. (2014). Evaluation of a stepwise, multiobjective, multivariable parameter optimization method for the APEX model. J. Environ. Qual., 43(4), 1381-1391. https://doi.org/10.2134/jeq2013.12.0509

Seobi, T., Anderson, S. H., Udawatta, R. P., \& Gantzer, C. J. (2005). Influence of grass and agroforestry buffer strips on soil hydraulic properties for an Albaqualf. SSSA J., 69(3), 893-901. https://doi.org/10.2136/sssaj2004.0280

Sharpley, A., Beegle, D., Bolster, C., Good, L., Joern, B., Ketterings, Q., ... Vadas, P. (2012). Phosphorus indices: Why we need to take stock of how we are doing. J. Environ. Qual., 41(6), 1711-1719. https://doi.org/10.2134/jeq2012.0040

Steglich, E. M., \& Williams, J. R. (2013). Agricultural Policy/Environmental eXtender model: User's manual version 0806. Temple, TX: Blackland Research and Extension Center. Retrieved from http://epicapex.tamu.edu/files/2014/10/APEX0806-UserGuide.pdf

Tuppad, P., Santhi, C., Wang, X., R. Williams, J., Srinivasan, R., \& H. Gowda, P. (2010). Simulation of conservation practices using the APEX model. Appl. Eng. Agric., 26(5), 779-794. https://doi.org/10.13031/2013.34947

Udawatta, R. P., \& Anderson, S. H. (2008). CT-measured pore characteristics of surface and subsurface soils influenced by agroforestry and grass buffers. Geoderma, 145(3), 381-389. https://doi.org/10.1016/j.geoderma.2008.04.004

Udawatta, R. P., Adhikari, P., Senaviratne, A. G. M. M. M., \& Garrett, H. E. (2015). Variability of soil carbon in row crop watersheds with agroforestry buffers. Agroforestry Syst., 89(1), 37-47. https://doi.org/10.1007/s10457-014-9740-3

Udawatta, R. P., Garrett, H. E., \& Kallenbach, R. (2011). Agroforestry buffers for nonpoint-source pollution reductions from agricultural watersheds. J. Environ. Qual., 40(3), 800-806. https://doi.org/10.2134/jeq2010.0168
Udawatta, R. P., Krstansky, J. J., Henderson, G. S., \& Garrett, H. E. (2002). Agroforestry practices, runoff, and nutrient loss. $J$. Environ. Qual., 31(4), 1214-1225. https://doi.org/10.2134/jeq2002.1214

Udawatta, R. P., Motavalli, P. P., \& Garrett, H. E. (2004). Phosphorus loss and runoff characteristics in three adjacent agricultural watersheds with claypan soils. J. Environ. Qual., 33(5), 1709-1719. https://doi.org/10.2134/jeq2004.1709

Udawatta, R. P., Nygren, P., \& Garrett, H. E. (2005). Growth of three oak species during establishment of an agroforestry practice for watershed protection. Canadian J. Forest Res., 35(3), 602-609. https://doi.org/10.1139/x04-206

Vadas, P. A., Good, L. W., Moore, P. A., \& Widman, N. (2009). Estimating phosphorus loss in runoff from manure and fertilizer for a phosphorus loss quantification tool. J. Environ. Qual., 38(4), 1645-1653. https://doi.org/10.2134/jeq2008.0337

Verbree, D. A., Duiker, S. W., \& Kleinman, P. J. A. (2010). Runoff losses of sediment and phosphorus from no-till and cultivated soils receiving dairy manure. J. Environ. Qual., 39(5), 17621770. https://doi.org/10.2134/jeq2010.0032

Vianello, M., Vischetti, C., Scarponi, L., \& Zanin, G. (2005). Herbicide losses in runoff events from a field with a low slope: Role of a vegetative filter strip. Chemosphere, 61(5), 717-725. https://doi.org/10.1016/j.chemosphere.2005.03.043

Waidler, D., White, E. M., Steglich, E. M., Wang, X., Williams, J., Jones, C. A., \& Srinivasan, R. (2011). Conservation practice modeling guide for SWAT and APEX. TR-399. College Station: Texas Water Resource Institute.

Wang, X., Williams, J. R., Gassman, P. W., Baffaut, C., Izaurralde, R. C., Jeong, J., \& Kiniry, J. R. (2012). EPIC and APEX: Model use, calibration, and validation. Trans. ASABE, 55(4), 14471462. https://doi.org/10.13031/2013.42253

Williams, J. R., \& Izaurralde, R. C. (2006). The APEX model. In V. P. Singh \& D. K. Frevert (Eds.), Watershed models (pp. 437482). Boca Raton, FL: CRC Press.

Williams, J. R., Harman, W. L., Magre, M., Kizil, U., Lindley, J. A., Padmanabhan, G., \& Wang, E. (2006). APEX feedlot water quality simulation. Trans. ASABE, 49(1), 61-73. https://doi.org/10.13031/2013.20244

Williams, J. R., Izaurralde, R. C., \& Steglich, E. M. (2012). Agricultural Policy/Environmental eXtender model: Theoretical documentation ver. 0806. Temple, TX: Blackland Research and Extension Center. Retrieved from http://epicapex.tamu.edu/files/2017/03/THE-APEX0806theoretical-documentation-Oct-2015.pdf

Zhang, X., Liu, X., Zhang, M., Dahlgren, R. A., \& Eitzel, M. (2010). A review of vegetated buffers and a meta-analysis of their mitigation efficacy in reducing nonpoint-source pollution. J. Environ. Qual., 39(1), 76-84. https://doi.org/10.2134/jeq2008.0496

Zhou, X., Helmers, M. J., Asbjornsen, H., Kolka, R., Tomer, M. D., \& Cruse, R. M. (2014). Nutrient removal by prairie filter strips in agricultural landscapes. J. Soil Water Cons., 69(1), 54-64. https://doi.org/10.2489/jswc.69.1.54 